\title{
Pregnancy and delivery of a women with Von Willebrand disease type 3: a case report
}

\author{
Reema Kumar Bhatt*, Shakti Panda, Triptpal Kaur
}

Department of Obstetrics and Gynecology, Army Hospital Research and Referral, Delhi, India

Received: 11 November 2019

Revised: 23 December 2019

Accepted: 26 December 2019

\author{
*Correspondence: \\ Dr. Reema Kumar Bhatt, \\ E-mail: reemakamalbhatt@yahoo.co.in
}

Copyright: (c) the author(s), publisher and licensee Medip Academy. This is an open-access article distributed under the terms of the Creative Commons Attribution Non-Commercial License, which permits unrestricted non-commercial use, distribution, and reproduction in any medium, provided the original work is properly cited.

\begin{abstract}
Von Willebrand disease (VWB) is the most common inherited bleeding disorder, found in approximately $1 \%$ of the general population, without ethnic differences. A multidisciplinary team ensuring readiness of availability of blood and blood products, perfect intraoperative hemostatis and administration of timely Von Willebrands factor are essential to prevent complications and improve perinatal outcome.
\end{abstract}

Keywords: Intrapartum and post-partum period, Multidisciplinary team, Von Willebrand disease

\section{INTRODUCTION}

Von Willebrand disease (VWB) is the most common inherited bleeding disorder, found in approximately $1 \%$ of the general population, without ethnic differences. ${ }^{1,2}$ In 1926, Erik Von Willebrand first described a familial bleeding disorder in which symptoms were more severe in children and young women. He also noted that the condition had autosomal inheritance and that blood transfusions improved bleeding symptoms. Since then knowledge of this disease has grown exponentially and is currently recognized as the most common inherited bleeding disorder. ${ }^{3-7}$ VWB disease is the result of a deficiency or defect in Von Willebrand factor (VWF) the large multimeric proteins which meditates platelet adhesions and serves as a carrier protein for factor VIII (FVIII). There are three major types. Type 1 is the result of a partial quantitative deficiency of a structurally normal VWF, and accounts for $70-80 \%$ of all VWD patients. Type 2 ( $20 \%$ of VWD patients) includes several qualitative defects in VWF that affects its multimeric structure or function. Patients with Type 3 VWD (5-10\% of VWD patients) are homozygous or doubly heterozygous for two mutant VWF alleles, with a resulting complete deficiency of VWF and a secondary severe deficiency of FVIII. Although the autosomal inheritance pattern predicts that both sexes should be equally affected, there is a higher frequency of symptomatic VWD in women because of the hemostatic challenges of menses, pregnancy and delivery. ${ }^{8-10}$ There is a progressive increase in FVIII and VWF levels during normal pregnancy. ${ }^{11}$ The challenge of managing Von Willebrand disease is the availability of Factor VIII with vigilant care to be taken during antenatal, intra-partum and postnatal period.

\section{CASE REPORT}

This 2-year-old primigravida spontaneous conception a known case of VWD type 3 at 36 week +4 days of period of gestation was transferred to our hospital for delivery with no previous antenatal checkup at our hospital with no genetic evaluation. On history patient had history of excessive blood loss during her periods and she was put on continuous oral contraceptive pills since menarche. There was no bleeding from nose, gums 
or bleeding in joints in childhood. During pregnancy there no history of bleeding from nose and gums or that of threatened abortion. Her brother had also been suffering from similar disease.

On examination general condition of patient was good and there was no pregnancy related complications. Her $\mathrm{Hb}$ was $11 \mathrm{gm} / \mathrm{dl}$. APPT- C-35 sec and T-48 sec, VWF $01 \%$ and Factor VIII-04\%. All the other antenatal investigations and test for fetal well-being were within normal limits. As this patient reported late in the pregnancy and in the absence of maternal genetic evaluation, prenatal diagnosis could not be offered to her to prognosticate the fetus

She remained asymptomatic and was managed conservatively. There was no requirement of FVIII-VWF concentrate nor any blood products during antenatal period. However, in consultation with the hematologist VWF was demanded, dose was calculated and there was preparedness in the eventuality of any emergency. She spontaneously went into labor at 40 weeks POG when she was administered $2500 \mathrm{u}$ units of VIII-VWF at the onset of labor.

Table 1: Relation of VWF and VIII levels with post op day and action taken.

\begin{tabular}{|lllll|}
\hline Day of surgery & VIII level & VWF level & APTT & VIII-VWF transfused \\
\hline 0 & $93 \%$ & $62 \%$ & C-35 sec, T- 37.3 sec & $2500 \mathrm{U}$ \\
\hline $1^{\text {st }}$ & $132 \%$ & $43 \%$ & C $-32 \mathrm{sec}, \mathrm{T}-39 \mathrm{sec}$ & $1000 \mathrm{U}$ \\
\hline $2^{\text {nd }}$ & $160 \%$ & $64 \%$ & $\mathrm{C}-33 \mathrm{sec}, \mathrm{T}-37.4 \mathrm{sec}$ & \\
\hline $3^{\text {rd }}$ & $125 \%$ & $44 \%$ & $\mathrm{C}-35 \mathrm{sec}, \mathrm{T}-48.2 \mathrm{sec}$ & \\
\hline $4^{\text {th }}$ & $48 \%$ & $15 \%$ & $\mathrm{C}-35 \mathrm{sec}, \mathrm{T}-50.7 \mathrm{sec}$ & $1000 \mathrm{U}$ \\
\hline
\end{tabular}

Her blood investigations revealed APTT- C- $35 \mathrm{sec}$ and T- 39 sec, Factor VIII levels were - 93\%, VWF levels were $-62 \%$. She was taken up for caesarean section due to Non progress of labour. Team of anesthesiologists selected general anaesthesia with acid aspiration prophylaxis for surgery. Cesarean was performed and perfect hemostasis was ensured at each step with cauterization of minor bleeding points. The bleeding after placental separation was not excessive. Uterus was repaired in two layers; Intraperitoneal drain was placed as post op bleeding was anticipated. Patient was monitored intensively in the post-op period. In the evening patient started oozing from wound and drain site which was controlled with compression bandage however this ooze continued for 2 days where was requirement of administration of Von Willebrands factor.

On $1^{\text {st }}$ post op day- Hb-15 gm /dl, platelet-1.09 lakh and total drain output was about - $1000 \mathrm{ml}$, bloody in nature. No PPH or bleeding from any other site. On $2^{\text {nd }}$ post-op day - total drain $=250 \mathrm{ml}$ sero-sanguineous in nature and drain removed. Stitches were removed on day 14 and patient was discharged to home. The association of the levels of VWF and the requirement of factor infusion is depicted in Table 1.

\section{DISCUSSION}

The hemostatic response to pregnancy depends on both the type and severity of the disease. Most women with type 3 VWD have no improvement in FVIII and VWF levels during pregnancy, although an increased FVIII levels has been rarely reported. ${ }^{12,13}$ VMF levels may fall precipitously after delivery in women with VWD. ${ }^{14}$ The postpartum fall in VMF explains the risk of post-partum hemorrhage, even in women with type 1 disease. Since
FVIII and VMF levels do not increase significantly until the second trimester, women with VMD remain at risk from bleeding in early pregnancy. ${ }^{12}$ Keeping in mind the high possibility of bleeding in the post-partum period, patient was prophylactically given VWF at the onset of labor and an extra dose post-delivery. Though the patient was asymptomatic in the antenatal period she didn't require any VWF supplementation, but with the anticipation of bleeding in the patient blood and blood products was kept ready in the blood bank to meet any emergency. Meticulous execution of surgery was carried out without much blood loss so as to minimize the possibility of any intra-partum bleeding and prophylactic placement of intraabdominal drain. Management of VWD during pregnancy should ideally include obstetricians, hematologist and blood bank personnel. During the course of pregnancy, one of many physiologic changes is an increase in several components of the clotting cascade; which includes both FVIII and VWF levels. Consequently, many patients with VWD reach normal levels of both FVIII and VWF at term. There seems to be no consensus in the literature as to how often levels of FVIII and VMF:RCo must be monitored. However, there is an agreement that, at the very minimum, levels should be determined during the third trimester. ${ }^{1,15}$ Pregnant women with VMD are at higher risk of hemorrhagic complications, mainly during the post-partum period. Such events are far more common if both FVIII and VMF:RCo levels are $50 \mathrm{IU} / \mathrm{dl}$. Overall, $16-29 \%$ of women with VMD will have postpartum hemorrhage within the first 24 hours of delivery, and 20$29 \%$ women will experience delayed postpartum bleeding. The third stage of labor should be managed actively. Procedures that potentially could increase the risk of hemorrhage (e.g. pudendal blocks, episiotomies, fetal scalp electrodes or operative vaginal deliveries) 
should be avoided if possible. The usual loading dose of these products is $40-60 \mathrm{IU} / \mathrm{kg} .{ }^{16} \mathrm{VMF}$ concentrates are dosed primarily on the basis of VMF:RCo units and secondarily on the basis of FVIII units. Infusions ideally should start before delivery until levels of 50IU/dl are achieved for both VMF:RCo and FVIII levels. Such levels should be maintained for at least 3-5 days after delivery. Levels should be followed daily, and the need for repeated doses should be tailored accordingly. Maintenance dose usually range between 20 and $40 \mathrm{IU} / \mathrm{kg}$ every 12-48 hours. As started before, because the risk of delayed post-partum hemorrhage, laboratory monitoring may be needed for 2 weeks after delivery to correctly identify those patients who will require prolonged prophylaxis with either VMF concentrate.

\section{Genetic counseling and prenatal diagnosis}

Genetic counseling about the risk of disease transmission and its variable expression should be provided to all women with VWD. This is particularly important for families with a child with type 3 VWD because each subsequent child has a $25 \%$ chance of inheriting a similar severe disease. Prenatal diagnosis of VWD is performed by analysis of DNA extracted from fetal cell obtained by CVS at 10-12 weeks or amniocentesis at 16-18 weeks of gestation. In our case the prenatal diagnosis was not offered to the patient as she had presented late in the antenatal period. However, she is planned for genetic evaluation now to offer prenatal diagnosis in the next pregnancy.

\section{CONCLUSION}

The management of pregnancy with VWD entails involvement of a multidisciplinary team consisting of hematologist, critical care specialist, senior obstetricians and neonatologist with strict vigilance, thorough intraop haemoststis and administration of Von Willebrands factor especially in the intrapartum and post-partum period are critical and recommended for effective management of pregnancy with VWD 3.

\section{Funding: No funding sources}

Conflict of interest: None declared

Ethical approval: Not required

\section{REFERENCES}

1. Rodeghiero F, Castaman G, Dini E, Epidemiological Investigations of the preevalnce of Von Willebrand's disease. Blood. 1987;69:454-9.

2. Broxson EH, Tucker EL, Giroux DS, Shults J, Abshire TC. Prevalence of Von Willebrand's disease in children: a multiethnic study. $\mathrm{J}$ Pediatr. 1993;123:893-8.

3. James AH. Von Willebrand's disease. Obstet Gynecol Surv. 2006;61:136-45.

4. Lee CA, Abdul-Kadir R. Von Willebrand's disease and women's health. Semin Hematol. 2005;42:42-8.

5. Kujovich JL. Von Willebrand disease and menorrhagia: prevalence, diagnosis and management. Am J Hematol. 2005;79:220-8.

6. Gojnic M, Fazlagic A, Likic I. New approach of the treatment of Von Willebrand's disease during pregnancy. Arch Gynecol Obstet. 2005;273:35-8.

7. Fedirici AB, Mannucci PM. Advances in the genetic and treatment of Von Willebrand's disease. Curr Opin Pediatr. 2002;14:23-33.

8. Sadler JE, Mannucci PM, Berntrop E, Bochkov N, Boulyjenkov V, Ginsburg D, et al. Impact, diagnosis and treatment of Von Willebrand's disease. Thromb Haemost. 2000;84:160-74.

9. Silwer J. Von Willebrand's disease in Sweden. Acta Paediatr Scand Suppl. 1973;238:1-159.

10. Miller $\mathrm{CH}$, Graham JB, Goldin LR, Elston RC. Genetics of classic Von Willebrand's disease. I. Phenotypic variation within families. Blood. 1979;54:117-36.

11. Sie P, Caron C, Azam J, Goudemand J, Grandjean H, Boneu B, et al. Reassessment of Von Willebrand factor (VWF), VWF propeptide, factor VIII. C and plasminogen activator inhibitors 1 and 2 during normal pregnancy. Br J Haematol. 2003;121:897903.

12. Kadir RA, Lee CA, Sabin CA, Pollard D, Economides DL. Pregnancy in women with Von Willebrand's disease or factor XI deficiency. Br J Obstet Gynaecol. 1998;105:314-21.

13. Caliezi C, Tsakiris DA, Behringer $\mathrm{H}$, Kuhne $\mathrm{T}$, Marbet GA. Two consecutive pregnancies and deliveries in patient with Von Willebrand's disease type 3. Haemophilia. 1998;4:845-9.

14. Hanna W, McCarroll D, McDonald T, Painter P, Tuller J, Chen J, et al. Variant Von Willebrand's disease and pregnancy. Blood. 1981;58:873-9.

15. Mannucci PM. Treatment of Von Willebrand's disease. N Engl J Med. 2004;351:683-94.

16. Sadler JE, Budde U, Eikenboom JC. Working party on Von Willebrand's disease classification: update on the pathophysiology and classification of Von Willebrand's disease: a report of the subcommittee on Von Willebrand factor. J Thromb Haemost. 2006;4:2103-14.

Cite this article as: Bhatt RK, Panda S, Kaur T. Pregnancy and delivery of a women with Von Willebrand disease type 3: a case report. Int J Reprod Contracept Obstet Gynecol 2020;9:881-3. 